\title{
Changes in the structure of earnings of informal street traders
}

\author{
Author: \\ Chris W. Callaghan ${ }^{1}$ \\ Affiliation: \\ ${ }^{1}$ School of Economic and \\ Business Sciences, University \\ of the Witwatersrand, \\ South Africa \\ Correspondence to: \\ Chris Callaghan \\ Email: \\ chris.callaghan@wits.ac.za \\ Postal address: \\ Private Bag 3, Johannesburg \\ 2050, South Africa \\ Dates: \\ Received: 29 Mar. 2013 \\ Accepted: 29 Oct. 2013 \\ Published: 19 May 2014 \\ How to cite this article: \\ Callaghan, C.W., 2014, \\ 'Changes in the structure of \\ earnings of informal street \\ traders', Acta Commercii \\ 14(1), Art. \#193, 13 pages. \\ http://dx.doi.org/10.4102/ \\ ac.v14i1.193

\section{Copyright:} \\ (C) 2014. The Authors. \\ Licensee: AOSIS \\ OpenJournals. This work \\ is licensed under the \\ Creative Commons \\ Attribution License.
}

Purpose/objective: The purpose of this research is to investigate the influence of the 2008 xenophobic events on the structure of earnings of street traders in inner-city Johannesburg and to provide recommendations to policymakers.

Problem investigated: The xenophobic events of 2008 are well documented, but absent from the literature is the potential influence on the earnings of foreign street traders. This study investigates this influence through analysis of data from before and after the events.

Design and methodology: The study applies an exploratory cross-sectional research design using data from three different samples. Mann-Whitney and Chi-squared measures are applied together with exploratory multiple linear regression analysis to generate insight into the relationships between earnings and differences by origin.

Findings and implications: In 2009 the earnings structure of the sector changed. In 2008 and 2010, the earnings of foreign traders are higher, whereas in 2009 these traders earned less than local traders. It is argued that the xenophobic events might have resulted in a temporary restructuring of earnings.

Originality or value of the research: This study makes a contribution through exploratory findings that document a change in the structure of earnings of foreign street traders.

Conclusion: A change in the structure of earnings of foreign street traders occurred after the xenophobic events of 2008. Although association cannot ascribe causality, it is argued that this change may be related to these events.

\section{Introduction}

Within the global context of increasing demographic diversity, South Africa has a relatively unique history. In South Africa, apartheid gave way to democratic governance with the first democratic elections of 1994 (Crush 1999; Harris 2002). However, according to Harris (2002:169), 'the shift in political power has brought about a range of new discriminatory practices and victims'; one 'such victim is "The Foreigner"'. In May 2008 South Africa experienced xenophobic events that cost the lives of more than 70 people and resulted in the displacement of about 120000 people, these amongst the most powerless in this society (Duncan 2012): 'the poorer and more vulnerable' (Verryn 2008:i). This article makes the argument that the relative earnings of street traders of foreign origin decreased relative to local traders in the year following these events.

Xenophobia, a dislike, hatred or fear of foreigners, has been associated with violence by South Africans towards immigrants (Harris 2002). Xenophobic violence has increasingly become a feature of South African society, subsequent to the new democratic dispensation (Gastrow \& Amit 2012; Harris 2002; Hussein 2012). Differences in attitudes toward foreigners have also served to make these people targets of crime (Harris 2002).

The particular targets of South African xenophobic violence have, however, not been foreigners in general, but specifically those from other African countries (Gastrow \& Amit 2012; Harris 2002). Over the past decades, the significant political, social and economic changes in the country, and on the continent, have resulted in inflows of migrants (from other areas of the country) and immigrants (from other countries) into the country's cities (Peberdy \& Rogerson 2003). Johannesburg in particular has experienced inflows of migrants and immigrants that have compounded problems associated with relatively high levels of societal unemployment, and posed challenges for local economic development (Rogerson 1997).

The inflows of both migrants and immigrants into the cities (Crush 1999) have swelled the ranks of the informal sector (Peberdy \& Rogerson 2003). Informal sector enterprise, or generally unregulated and unregistered activities that are typically outside of the formally regulated 
economy, has a significant role to play in contexts of high unemployment. Previous estimates suggest that about five million people are supported by those who work in the country's informal sector (Ligthelm 2006). About five to eight thousand traders ply their trade in the Johannesburg informal sector (O'Reilly 2004; Van Rooyen \& Antonites 2007). Approximately $60 \%$ of the inner-city Johannesburg street trading sector has been found to be of foreign origin (Callaghan \& Venter 2011). In such a context, the inner-city street trading sector is not expected to have been isolated from the xenophobic events of 2008 within the city.

In this article an argument is presented: that the earnings of inner-city street traders of foreign origin were significantly influenced by the xenophobic events of 2008. This argument is presented through the lens of post-positivism (Cresswell 2003). The specific changes in the structure of street trading earnings are therefore investigated in a longitudinal analysis that extends across the years 2008, 2009 and 2010. The findings of this study are considered to be relevant to, and to generalise to, other contexts to the extent that they are similar to this context, and to the extent that such conditions might recur in future. The aim of this article is therefore not to investigate xenophobia itself, or the causes of xenophobia, but to investigate changes in the earnings of street traders over the years 2008, 2009 and 2010 and to offer an argument that these changes may be related to the xenophobic events of 2008 .

\section{Problem statement and research objectives}

The problem addressed in this research is the lack of knowledge around the potential impact of xenophobic events upon the financial structure of the street trading sector, and specifically with regard to four groups of street traders: (1) traders of foreign origin (termed immigrant traders), (2) traders of South African origin, (3) traders of local origin that are not of Johannesburg origin (termed migrant traders) and (4) traders of Johannesburg origin. This study therefore attempts to address this deficiency in the informal sector literature.

The objective of this research is to develop knowledge that can provide insight into how the upliftment of people in informal work can be enabled. It is argued that such knowledge is particularly salient, given the potential for further political or social instability (Neocosmos 2008) that might create a climate for further xenophobic events. It is argued that the influence of ongoing societal-level xenophobia is an important contextual variable in informal sector commercial research. The primary objective of this research is therefore to test the theory that predicts differences in the sector between groups of street traders that differ by origin. The study spans the years 2008, 2009 and 2010. The 2008 survey was undertaken in the month before the xenophobic events. The research questions posed in this study are:

1. What are the differences in the structure of financial and contextual associations in the sector by foreign, South African (non-Johannesburg) and Johannesburg origin?
2. What was the potential impact of the xenophobic events of 2008 on the earnings structure of the inner-city street trading sector?

In this study the structure of financial capital associations refers primarily to the associations of earnings and initial investment. However, other contextual factors, such as age, years spent in Johannesburg, formal education, time in the sector, continuance satisfaction and product provision, are also included in this analysis as these are deemed to also be peripherally relevant to the financial structure of the sector. The article proceeds as follows. Firstly, theory is introduced and hypotheses are derived. Then, the methodology applied in this research is discussed. Thereafter, the results are reported and discussed in relation to each of the tested hypotheses. The article concludes with a summary of the findings and recommendations for further research and for practice. At this nexus, theory relating to xenophobia is discussed in order to adequately contextualise the study.

\section{Xenophobia theory}

The conceptual foundations of the research are now considered in order to provide a synthesis and critical evaluation of the relevant literature and to provide conceptual support for the thesis advanced in the article. The thesis of this article is that a change in the structure of earnings of informal street traders of foreign origin subsequent to the xenophobic events of 2008 is plausible, given the predictions of theory and evidence in the literature relating to xenophobia.

However, in order to make this argument, it is necessary to review the theory that predicts that xenophobic events might be associated with changes in the structure of earnings of foreign traders. The following discussion of the literature will therefore provide insight into the potential consequences of xenophobia across different contexts.

Despite the fact that associative statistical testing cannot ascribe causality, in the article, on the basis of statistical testing, a single, overarching and coherent argument is made: that there are earnings-related consequences for innercity street traders of foreign origin when xenophobic events of the scale experienced in May 2008 occur and that these can last up to a year later.

This article will therefore present evidence that a change in the structure of the earnings of individuals of foreign origin occurred subsequent to the events in 2008, and was present a year later. Theory that predicts that this is possible will be related to these findings in order to support this argument.

To fully contextualise the article, relevant theory and literature that relates to xenophobia will now be considered: (1) firstly on the global level, then (2) on the South African societal level in general and finally (3) at the level of innercity street trading. In this literature review, literature is used that tracks the development of the xenophobia literature over time. This will provide a temporal perspective of this 
phenomenon so that the empirical study can be located in relation to previous work in this area.

\section{The global context}

In the international context, xenophobia literature offers different perspectives of the phenomenon and its consequences. One of these perspectives is based on the link between nationality, or migration related to nationality, and xenophobia. Since 'the end of the colonial period, international migration has become a truly global phenomenon', as the structural forces underlying migration (primarily economic but also environmental and social) have intensified (Crush \& Frayne 2007:3). The most common measure of migration is the United Nations concept of 'migrant stock - defined as the number of foreign-born residents in the population at the time of the most recent Census' (Crush \& Frayne ibid:3). Ultimately, 'the causes of migration are multiple, scale-dependent and often country-specific' (Crush \& Frayne ibid:4).

Migration is found to be related to xenophobia in both 'developed' and 'developing' contexts. Based on a rationale of differences in citizenship and immigration policy, research undertaken across Australia, Germany, Britain and Sweden offers the notion that civic national identity and national pride are typically associated with xenophobia: people with a civic national identity are expected to be less xenophobic than people with an ethnic national identity (Hjerm 1998).

Globally, debates have long existed about how xenophobia, or the 'denigration of individuals or groups based on perceived differences' (Hjerm 1998:335), can be addressed; two different approaches are typically followed. The first approach entails liberal forms of multiculturalism (equality and a laissez-faire process) (Hjerm ibid). According to the second strategy, communitarian approaches (where active political policies foster ethnic integration) are followed (Hjerm ibid). However, in these implementations, these approaches typically reflect the state and its policies with regard to ethnic and cultural issues (Hjerm ibid). The role of the state is therefore an important dimension in the way xenophobia can influence people and their activities in certain contexts.

The dominance of ethic majorities in nation states is another important dimension of xenophobic contexts. A dominant language can impose inequality on minorities and introduce cultural oppression and marginalisation (Hjerm 1998). Germany can be taken to represent the ethnic 'ideal type' of country according to Hjerm because of its prioritisation of ethnicity in public policies. In contrast, Australia and Canada conform to the multicultural model or 'type' (Hjerm ibid). For Hjerm (ibid:346), a problem 'arises if the political efforts towards a separation of the civic and ethnic do not successfully alter people's attitudes toward a more civic national identification and politically-based national pride'. Inner-city street traders exist within a context in which South African ethnic groups dominate.
On a global basis, the United Nations World Conference against Racism, Racial Discrimination, Xenophobia, and Related Intolerance (UN-WCAR) has undertaken a multiyear, multinational process in order to raise awareness of issues relating to xenophobia (Myers, Lange \& Corrie 2003). Despite the emergence of a strong lobby of non-governmental organisations that oppose xenophobia on a global basis (Myers et al. 2003), explicitly xenophobic political parties persist; an example of this is the second-place victory of the National Front Party in the 2002 French elections (Roemer \& Van der Straeten 2005). In this case, over the period 1998-2002, a shift in the sentiment of voters was found from economic issues to 'non-economic issues such as immigration and security/lawand-order' (Roemer \& Van der Straeten ibid:95).

It is difficult to differentiate between the causes and effects of xenophobia across different national contexts. In relation to evidence from France, Roemer and Van der Straeten (2005) argue that levels of overt xenophobia reflected in political processes are related to a reduction in the size of the public sector. Le, Van der Straeten and Roemer (2006) make a similar argument in relation to the economies of the United States, the United Kingdom, France and Denmark. In Denmark, the Social Democratic Party, associated with the introduction of the welfare state, lost in the 2001 elections to a party that subsequently joined in a coalition with the Danish People's Party, a 'right-wing, anti-immigrant' political party (Roemer \& Van der Straeten 2006). Xenophobic attitudes are also therefore seemingly reflected in political processes and outcomes. Elected governments, including in South Africa, might not be independent of the influence of xenophobic attitudes of voters.

A common theme in this body of international literature is that xenophobic attitudes in a society have certain consequences, which are borne by minority groups, particularly those of foreign origin. However, according to Crush and Frayne (2007:1), much of the international debate around migration 'is hampered by the absence of sound, reliable national and local data'. This article attempts to relate data to this debate.

On the African continent, initiatives to formulate policy responses around the issues around migration have been 'limited at the national level' (Crush \& Frayne 2007:2).

The notion of national boundaries on the African continent, however, is primarily a legacy of colonialism (Mamdani 2001). For Mamdani (2001:51), certain colonial assumptions are typically embedded in 'various theories of modernisation', namely (1) that 'colonial cultures were not grounded in historical processes', and (2) 'that colonial contact marked the beginning of a history for these societies'. State-generated political identities differ from market-based and cultural identities and there is a 'growing tendency to root causes of violence in cultural difference - now ominously called a clash of civilisations' (Mamdani ibid:652).

However, for Mamdani (2001), neither 'Marxists nor nationalists tried to historicise race and ethnicity as 
political identities undergirded and reproduced by colonial institutions'. These colonial institutions, according to PanAfricanists, created artificial boundaries without regard to the people of Africa (Mamdani 2001). Mamdani (ibid:653) contests the perspective that boundaries are natural in the first place: all 'boundaries are artificial; none are natural'. Further, with 'the growing power of finance capital, however, all boundaries become porous' (Mamdani ibid:653). It is argued that whereas for street traders borders might be porous, and interactions between people of different nationalities more common, the differences between traders by national origin can have implications for street trader earnings following xenophobic events.

Seminally, Chipkin (2007) extends the analysis of continental nationalism into the context of South Africa, and argues that South Africans have emerged as a people based more on political goals than on cultural goals. The importance of nationalist struggle for state power is framed as the backdrop against which the emergence of South African identity can be understood (Chipkin ibid). Ethical values as democratic norms are a necessary condition for true citizen democracy to emerge, according to Chipkin.

Despite World Bank findings that have concluded that international migration can generate welfare gains for migrants, and for both their countries of origin and settlement, migrants are 'more often seen as a threat to citizen's rights and welfare', and 'opposition to migration has shaded into intolerance and xenophobia' (Crush \& Frayne 2007:2).

South-South migration, of which South Africa is a recipient, is primarily driven by economic motives (Crush \& Frayne 2007). 'Contemporary official and public policy [communication] in southern Africa continues to view migration as essentially a bad thing'; there is 'a pervasive and misleading view that every job occupied by a foreign migrant, at whatever level, is one job less for a citizen' (Crush \& Frayne ibid:13). Similarly, numbers of irregular migration are exaggerated and 'illegal status is conflated with criminality' (Crush \& Frayne ibid:14).

In contrast to the ideology of Pan-Africanism, under the post-apartheid government in South Africa, initially mooted notions of free movement of migrants have 'been replaced by tough migration control' and an 'obsession with the numbers is itself "racialising" migrant workers'. These numbers are 'constructed and stigmatised as a "problem" as has been seen most notably in Britain in the 1970s' (Trimiklinionitis, Gordon \& Zondo 2008:1325). For Trimiklinionitis et al. (ibid:1331) 'we cannot but refer to the acts of the post-apartheid state against Black migrants as "racist"; there is no reason why one should refer to this policy, practice, and exclusionary ideology merely as "xenophobic"; otherwise we may be making light of what is essentially a continuation of the policies of the apartheid regime and what appear to be state practices across many countries of the globe'.

Migrants from north of South Africa's borders typically face deskilling and under-employment, and downward status mobility in South Africa (Moorhouse \& Cunningham 2010). State actions such as the Zimbabwe 'Operation Murambatsvina', or 'Operation Clear the Filth' 'destroyed the homes and businesses of three quarters of a million Zimbabweans, heralding mass starvation', resulting in an influx of migrants into South Africa (Moorhouse \& Cunningham ibid:588). With no other alternative for employment, many of these migrants end up in the informal sector (Moorhouse \& Cunningham ibid). Migrants facing work in deskilled contexts are more vulnerable to recessionary forces and are also more vulnerable to injury and death resulting from xenophobic violence (Moorehouse \& Cunningham ibid; Worby, Hassim \& Kupe 2008).

\section{The influence of the World Cup in 2010 and overarching economic conditions}

The study was undertaken over the years 2008, 2009 and 2010. The World Cup in 2010 might have influenced the informal street trading sector. For Ndlovu-Gatsheni (2011), the hosting of the World Cup by South Africa might have resulted in a form of 'banal nationalism', where diverse groups were united in a form of national unity that was inherently temporary.

The 'outbreak of xenophobic attacks in May 2008 ... ran counter to the philosophies of "ubuntu" and African Renaissance that Mbeki was articulating' (Ndlovu-Gatsheni 2011:281). Ubuntu is the philosophy that 'you are a person because of other people', and the African Renaissance is 'a model of a working, multiracial "rainbow" society and a successful transitional African state' (Ndlovu-Gatsheni 2011:281).

For Ndlovu-Gatsheni (2011:281), the xenophobic events, and racial tensions associated with the 'singing of the liberation war song Shoot the Boer' by the African National Congress Youth League, which together with other events were 'threatening to tear the nation apart, the hosting of the FIFA World Cup came as a blessing to those nationalists committed to continuing the project of nation building initiated by Nelson Mandela'. The World Cup was therefore a very 'important therapeutic and cathartic' process that supported national unity over this period, according to Ndlovu-Gatsheni (ibid:282). South Africa itself, for NdlovuGatsheni (ibid:283), 'can best be understood as an ever developing idea, from being a mere geographical expression to an identity of the people'; it is an accident of history that is not free from contestation.

The hosting of the World Cup was not pro-poor as smallscale traders were not given the opportunity to sell to football supporters (Ndlovu-Gatsheni 2011). Nonetheless, in terms of the entrepreneurial performance of Johannesburg street traders, 'FIFA related opportunities had a significant impact on the introduction of new products and services as well as on customer service delivery' (Venter et al. 2012:457). 
Further, at 'the same time such opportunities led to a reliance on past experience as well as networks in identifying the opportunity' (Venter et al. 2012:457). It is acknowledged that the positive influence of the hosting of World Cup football games in Johannesburg might have produced positive externalities for the inner city traders, which might have provided a 'normalising' influence two years on from the xenophobic events of 2008.

Economic conditions over the period of the study reflect a positive state existing into 2008, with a trend of a decline in the category of discouraged work seekers up until June 2008 (Statistics South Africa 2008). The unemployment rate had declined from 26.5\% in March 2005 to $23.1 \%$ for the period April to June 2008 (Statistics South Africa 2008).

However, for the period July to September 2008, the informal sector was found to have lost approximately 165000 participants (Statistics South Africa 2008). It is unclear if people were leaving the sector due to the influence of the xenophobic events earlier in the year. Nonetheless, the unemployment rate did rise over 2009 to a high of $24.5 \%$ by the end of the year and to $25.3 \%$ by the end of 2010 (Trading Economics 2013). It is argued that if this trend towards increased unemployment existed across 2009 and 2010 then it might have been a factor to which all street traders, irrespective of origin, may have been exposed to. In other words, the earnings of all street traders might be similarly exposed to the economic downturn of 2009 and 2010. Having contextualised the phenomenon of xenophobia, other theory that seeks to explain further aspects, or boundary conditions, of its manifestation is now discussed.

According to the broader literature, three theoretical hypotheses have also been advanced to explain the phenomenon of xenophobia (Harris 2002). Firstly, the 'scapegoating' hypothesis locates the phenomenon within a context of competition for resources, and similar conceptions such as relative-deprivation theory predict that, in contexts of societal dissatisfaction, deprived individuals will be more likely to express frustration targeted at minorities (Harris ibid). Scapegoating can therefore result from social comparison, where foreigners are blamed for 'taking' jobs, houses and other resources from locals (Harris ibid). The media can contribute to these stereotypical perspectives of foreign-born individuals, as reflected in the coverage of the 2008 xenophobic violence (Harber 2008). According to this perspective, street traders of foreign origin are particularly vulnerable, because they operate on street sides and are often in, or in close proximity to, areas that are dominated by deprivation and scarcity of resources, including the inner city. According to this theoretical perspective, it is predicted that street traders of foreign origin are particularly vulnerable to the influence of xenophobia. Customer commitment and ongoing or long-term relationships with customers is important for retail success (Roberts-Lombard 2009). It is possible that customer relationships might be influenced by xenophobic attitudes in a resource-constrained context such as the Johannesburg inner city.
Secondly, the 'isolation' hypothesis posits that with the borders of South Africa opening up, South Africans have come into increasing contact with previously unknown groups (Harris 2002). There is also an internal dimension to the isolation hypothesis: tolerance of differences has not typically been a feature of South Africa's history (Harris ibid). According to this conception, over time, and after exposure to other groups, xenophobia might reduce; other groups are eventually no longer viewed as 'new' or associated with as much uncertainty. The 2008 xenophobic events, however, effectively occurred 14 years after the exposure of locals to groups of foreign origin.

Thirdly, the 'biocultural' hypothesis locates the phenomenon of xenophobia in biological or cultural differences which serve as indexical markers or signifiers, which identify individuals as 'different' (Harris 2002). Harris stresses, however, that these theories do not explain why xenophobia pervades the South African context, and suggests an alternative perspective. According to Harris, xenophobia is the result of mechanisms of nationalism within a country that is transitioning.

Other perspectives of xenophobia also offer insight into the phenomenon. Media stereotypes, particularly those that perpetuate a communication associated with representations of 'illegality', also encourage xenophobia (Harris 2002). The notion of street trader 'illegality' echoes this perspective. Street traders have been found to report that their choice of what stock to sell often depends on what they can carry when avoiding police (Tissington 2009).

Another perspective of xenophobia is of it being political communication (Neocosmos 2008). As such, a 'politics of fear' may exist in South Africa, which is underpinned by three components that exist as separate communications (Neocosmos ibid). These three communications are: (1) a state communication of xenophobia, (2) a communication 'of South African exceptionalism and (3) a conception of citizenship founded exclusively on indigeneity' (Neocosmos 2008:587).

The state communication of xenophobia is associated with a repatriation regime, associated with the 'removal' of individuals for deportation at the Lindela repatriation centre, which supports xenophobic conceptions that manifest at a societal level (Neocosmos 2008).

The communication of South African exceptionalism has its roots in differences between South Africans and the rest of the continent, as the extreme levels of wealth associated with 'neo-liberal' South Africa contrasts strongly with the rest of the continent (Neocosmos 2008). The communication of South African exceptionalism locates South Africans as exceptions, with those of foreign African origin as 'the Other'; South Africans are perceived as different along many dimensions from those from the rest of the continent, which further supports societal xenophobia (Neocosmos ibid). 
According to Neocosmos (2008), the indigeneity communication exists when degrees of indigenousness are legitimised as a route to acquire resources, jobs and other advantages.

Neocosmos (2008:592) argues that in the face of these three dominant communications in South African society, 'quasifascist politics' has manifested in South Africa, the 2008 xenophobic violence being a confirmation of his hypothesis. The solution to xenophobia has its roots in another communication: one rooted in the axiom of equality, where each individual has equal value in this society, where the country belongs to all that live within it (Neocosmos ibid).

Nationality is also a feature of the communication around notions of the new nation that South Africa is becoming (Harris 2002). Especially pertinent to the enablement of xenophobia is South Africa's 'culture of violence': social relations historically were ordered through violent means, and violence is still legitimised as a means to attain goals, in line with historical precedent, or in line with the legitimisation of violence in pursuit of political aims (Harris ibid). It is within this context that street traders of foreign origin are exposed to potential security threats associated with xenophobia. It is argued that this body of theory supports the prediction that the violent outbreaks of xenophobia in 2008 could be associated with changes in the structure of earnings relationships that are differentiated by national origin.

Within a context of threatened violence, mutual assistance and protection might constrain societal assimilation; immigrants from the rest of Africa tend to cluster together in their work lives as well as their home lives (Harris 2002). Individuals of foreign origin typically 'resist implantation into the soil on which they live and work, instead hovering above it by retaining loyalties to their countries of origin and orienting themselves toward a future outside South Africa' (Landau \& Monson 2007). Historical, regional and ethnic factors have been found to shape differences between groups with regard to their economic activities (Shapero \& Sokol 1982). These include ethnic differences in entrepreneurial self-efficacy (Urban 2006). It is predicted that street trading is no different: traders are expected to 'cluster' according to country of origin, and their trading patterns might be expected to reflect this.

Evidence exists of the hostility that host countries have harboured towards 'middlemen minorities', or groups of foreign origin that typically take up retail activities (Bonacich 1973). Fatal attacks on Somali traders, particularly in South African township areas, are ongoing (Hussein 2012). PanAfricanism, however, as a conception or an ideology that unites Africans across the continent, has been suggested as a counterpoint to the nationalist communication developing in South Africa (Landau \& Monson 2007).

This context, therefore, may offer researchers the opportunity to investigate the potential influence of the 2008 xenophobic events upon the earnings structure of individuals of foreign origin in the sector. An account of the xenophobic events of 2008 is offered by Worby et al. (2008):

On the evening of Sunday, 11 May 2008, a gang of young men in Johannesburg's Alexandra township forced their way into a hostel in London Road and initiated a merciless attack on residents they deemed to be 'foreigners'. From this spark, the murder, rape, and looting directed at the bodies and belongings of non-South Africans had spread within days from Alex to information settlements in Diepsloot and the East Rand, where a Mozambican man, Ernesto Alfabeto Nhamuavhe, was burned alive while bystanders laughed. Soon thereafter, similar attacks began to unfold in the provinces of KwaZulu-Natal and the Eastern and Western Cape. South African citizens speaking the 'wrong' languages - XiTsonga or SiPedi, for example - were also subjected to violent assault. By the time the violence had subsided in early June, some 62 people had died - a third of them South African. Hundreds had suffered grievous injuries and tens of thousands had been displaced from their homes, taking shelter in community halls and police stations, or fleeing in terror across the borders in anticipation of an uncertain future. (p. 1)

On the basis of the above discussion, it is argued that the investigation of differences in the structure of associations in this sector by foreign origin versus local origin is especially salient over this period. At this juncture the hypotheses are derived for testing.

\section{Hypotheses}

The demographic structure of the inner-city informal trading is expected to also reflect changes in official policy. These changes manifested most strongly after the democratisation of the country in 1994 (Peberdy \& Rogerson 2003). The implication of this is that the age distribution in the sector will differ by national origin. In order to verify and to contextualise these expected differences by national origin, Hypothesis $1 \mathrm{a}$ and Hypothesis $1 \mathrm{~b}$ are proposed: that there is a significant difference in age by South African origin, and that there is a significant difference in years spent in Johannesburg by South African origin.

Over-representation of foreign-born participants in small business is typical (Light 1984). Ethnic enclave theory also predicts that immigrant groups are more likely to develop horizontal and vertical structural relationships with each other (Reynolds 1991; Wilson \& Martin 1982). These structural relationships can offer other enterprise advantages, particularly in terms of raising finance (Reynolds 1991; Wilson \& Martin 1982). Hence, Hypothesis 1c is offered: that there is a significant difference in initial investment by South African origin.

Similarly, it is expected that in such a potentially discriminatory context more educated individuals of foreign origin would be expected to have relatively fewer opportunities in the formal sector, and might be relatively more likely to enter the informal sector, even temporarily. More educated individuals are increasingly emigrating towards relatively more wealthy countries (Belot \& Hatton 
2008). Therefore Hypothesis $1 \mathrm{~d}$ is posited: that there is a significant difference in formal education by South African and non-South African origin. Evidence has been found of differences in entrepreneurial earnings by country of origin, based on different types of motivations associated with the membership of immigrant groups (Basu \& Altinay 2002). If traders of foreign origin in such a sector are expected to have higher levels of resources and education then these traders would also be expected to have higher earnings, according to the predictions of human capital theory (Becker 1975). However, this prediction would rest upon the degree to which societal discrimination and xenophobic events are a vehicle for discrimination that can extend into the informal sector itself. Therefore Hypothesis 1e is proposed: that there is a significant difference in earnings by South African origin. In fact, it is argued that the xenophobic violence of 2008 can be expected to be associated with a perversion of the earnings structure of the sector.

If endowments of resources and education are higher for traders of foreign origin, notwithstanding the influence of societal xenophobia, it is expected that these resources will also enable an earlier exit from the sector to the formal sector or towards more sophisticated forms of enterprise (De Soto 1989). Therefore Hypothesis 1f is proposed: that there is no significant difference in time spent in the sector by South African origin.

If there is a fundamental difference in the experience of street trading due to the experience of xenophobic attitudes of the inner city population, and if security worries are of utmost concern in immigrants' lives (Harris 2002), then it might be expected that such individuals will be less satisfied with continuing in street trading. Therefore Hypothesis $1 \mathrm{~g}$ is offered: that there is a significant difference in continuance satisfaction by South African origin.

Traders of foreign origin might form social networks, or social groupings, on the basis of their common experience of the South African context (Harris 2002; Neocosmos 2008). Potential advantages have also been found to be associated with having access to social networks (Coleman 1988; Coulthard 2007; Dubini \& Aldrich 1991). To the extent that such networks might arise from such a common experience of the inner city context, traders of foreign origin might 'cluster' towards certain product provisions. Hypothesis $1 \mathrm{~h}$ is therefore proposed: that there is a significant difference in product provision, or what traders sell, by South African origin.

The theory introduced above relates to societal xenophobia targeted at individuals of foreign origin. The potential discrimination targeted at migrants, or traders from other areas of the country, has not been interrogated in the informal literature. Therefore, in order to establish some form of 'control' against which to validate the claims made about individuals of foreign origin in this sector, certain differences between migrant traders and traders of Johannesburg origin were also tested. Differences in age (Hypothesis 2a), initial investment (Hypothesis 2b), formal education (Hypothesis 2c) and earnings (Hypothesis 2d) were tested for this group. The research methodology applied in this research is considered next.

\section{Research methodology}

This research derives its precedent from the postpositive paradigm (Cresswell 2003). Postpositive knowledge claims about what warrants knowledge are based on certain ontological and epistemological assumptions (Cresswell ibid). Postpositivism differs from positivism in that the notion of the 'absolute truth' of knowledge is contested (Cresswell ibid). For Cresswell (ibid):

Postpositivism reflects a deterministic philosophy in which causes probably determine effects and outcomes. Thus, the problems studied by postpositivists reflect a need to examine causes that influence outcomes, such as issues examined in experiments. It is also reductionistic in that the intent is to reduce the ideas into a small, discrete set of ideas to test, such as the variables that constitute hypotheses and research questions. The knowledge that develops through a postpositivist lens is based on careful observation and measurement of objective reality that exists "out there" in the world. ... Thus, in the scientific method - the accepted approach to research by postpositivists - an individual begins with a theory, collects data that either supports or refutes the theory, and then makes necessary revisions before additional tests are conducted. (p. 7)

An exploratory descriptive research design was applied, premised on the postpositivist paradigm of research. In the following sections, data collection is first discussed. The data analysis process followed in this research is then introduced, with specific reference to statistical testing conducted.

\section{Data collection}

Data was collected from street trader respondents over the years $2008(n=339), 2009(n=308)$ and $2010(n=303)$. Data was sampled over the course of one day in each of the three years. The city of Johannesburg was sampled according to a sampling frame of city blocks that represented the distinct character of the inner city. Surrounding areas such as residential, industrial or transport-oriented blocks were excluded. The core area of the inner city was therefore demarcated, with city blocks south of Plein Street, west of End Street, north of Faraday Street and east of Sauer Street included in the sampling process. Ten per cent of the 228 blocks that comprised the inner-city street trading area were randomly selected, and the individual traders on these blocks were counted. On the basis of this process an estimated population size estimate of 5000 traders was obtained. A sample size calculation was applied in order to establish that the necessary inferences could be made from the statistical tests. Sample sizes of 300 were identified as acceptable for the three samples obtained in 2008, 2009 and 2010. Strict ethical processes were followed and, in keeping with these principles, refusals were unconditionally respected. However, due to the presence of refusals, strict proportionality of data collection 
was rendered impossible, and claims are therefore premised on the basis of convenience sampling.

\section{The measuring instrument}

The tested variables were justified for inclusion in the research on the basis of the review of the literature. This research follows the precedent of Dasgupta (2003): structural characteristics of the informal context are typically measured in a survey form. Initial investment was measured as the amount of money invested at the start of the street trading venture. Training attendance measured whether a street trader had attended the City of Johannesburg and University of the Witwatersrand street trading skills development programme. This was measured as a binary variable, with 1 representing previous attendance and 0 representing nonattendance. Gender was also measured as a binary variable, with male indicated as 1 and female as 0 . Age was measured in years. Years in Johannesburg referred to the number of years spent in Johannesburg since arrival in the city. Hours worked per day and days worked per week measured just that. Total education measured the number of years of education a street trader had completed (in 2009 and 2010; in the 2008 data an interval scale was used). Experience was measured as years spent in street trading. The operation of a City of Johannesburg rental stand was measured as a binary variable. Earnings were measured as gross earnings from sales per day. Continuance satisfaction was measured using Likert-type scales. This question measured the extent to which street traders were satisfied with continuing in street trading. The order of the questions was reversed, and Cronbach's alpha tests were used to check the internal consistency, or reliability, of the items. The Cronbach's alpha values for the continuance satisfaction items were .906 for the 2008 data, .742 for the 2009 data and .939 for the 2010 data. Exploratory factor analysis indicated that the continuance satisfaction items loaded with each other in each case. The instrument was piloted prior to use. The data analysis process is now discussed.

\section{Data analysis}

The data were analysed using SPSS and SAS statistical software. In order to test the hypotheses in a conservative manner, and in a way that did not require the removal of outliers and influential points that might have compromised the generalisability of findings to other contexts that include diverse individuals, the research design included nonparametric tests of difference as the primary form of testing. Therefore, Mann-Whitney tests were used. Chi-squared tests of association were also utilised. Exploratory multiple linear regression (MLR) was used in order to provide further insight into the differences between groups in the sector differentiated by origin. A multiple linear regression model was therefore run on the sample split by South African origin and Johannesburg origin. On the basis of the literature the following variables were included in the model: order of capture, exposure to training programmes, gender, age, years spent in Johannesburg, hours worked per day, initial investment, total education, experience (time spent in the sector), the operation of a rental stand and continuance satisfaction. For the model tested with earnings as the dependant variable, for traders of foreign origin only, the highest of the condition indices was 9.56. The eigenvalues summed to the number of variables in the model. The highest variance inflation factor was found to be 1.142 and the lowest tolerance value as found to be .876 . Multi-collinearity within the model was therefore taken to be at acceptable levels. The Durbin-Watson statistic was 1.69. Autocorrelation was not taken to be a problem with the model. The residuals of earnings per day were reasonably distributed according to a normal distribution. The residuals plotted against the predicted values for earnings per day reflected a reasonable scatter. No patterns were clearly visible in the plot. Tests of the Studentised residuals, Cook's distance and outlier and leverage diagnostics were conducted to ensure confidence in the MLR findings. The quartile-quartile (Q-Q) plot reflected a reasonably straight plot against the diagonal. For the model tested for the sample of respondents of South African origin, the highest of the condition indices was 6.63. The eigenvalues summed to the number of variables in the model, the highest of the variance inflation factors was 1.02 and the lowest of the tolerance values was .985. Multi-collinearity was also not considered a threat to the interpretation of the results of this model. The Durbin-Watson test statistic was 2.143. Autocorrelation was also not considered to be a problem for this model. For these models, the histogram distribution of the residuals for earnings was reasonably well distributed, in the shape of a normal distribution. The residual plots reflected a reasonable scatter. These models were considered have reasonably met the assumptions of multiple linear regression analysis.

\section{Limitations of the study}

Certain limitations are associated with the study. Firstly, as is the case with all quantitative research, causality cannot be claimed. Although the testing of changes in associations over time is appropriate for quantitative methods, further qualitative research is recommended in order to establish more fine-grained understandings of the causal mechanisms that underpin changes in the structure of earnings in the informal sector, particularly those relating to the potential influence of xenophobia. Secondly, the findings of this study are expected only to generalise to other contexts to the extent that they are similar to this context. As such, the findings might be less applicable to rural or suburban contexts of street trading than to large inner-city street trading contexts.

\section{Results and discussion}

The descriptive data of 2010 for the three primary groups, traders of foreign origin, traders of Johannesburg origin and traders of South African but not Johannesburg origin, are reported in Table 1. Traders of Johannesburg origin and of South African but not Johannesburg origin are grouped together as traders of South African origin in Table 2, which reports descriptive data for this group. Certain characteristics of the sample are discussed below. 
TABLE 1: Means, standard deviations, modes and medians (2010): Foreign Origin/Johannesburg origin/South African but not Johannesburg origin.

\begin{tabular}{|c|c|c|c|c|}
\hline Variable & Mean/\% & Standard Deviation & Mode & Median \\
\hline Initial investment & $1331 / 813 / 999$ & $1380 / 1092 / 1112$ & $550 / 350 / 250$ & $750 / 400 / 650$ \\
\hline Training attendance $\dagger$ & $5 / 17 / 13$ & - & - & - \\
\hline Gender † & $71 / 67 / 45$ & - & - & - \\
\hline Age & $31.9 / 33.4 / 38.3$ & $8.8 / 8.9 / 11.7$ & $27 / 24 / 39$ & $30 / 34 / 39$ \\
\hline Years in Johannesburg & $7.8 /-/ 14.5$ & $7.9 /-/ 9.9$ & $3 /-/ 20$ & $5 /-/ 12$ \\
\hline Hours worked per day & $10.6 / 10.5 / 10.9$ & $1.8 / 2 / 2.2$ & $11 / 9 / 9$ & $10.8 / 10.5 / 11$ \\
\hline Days worked per week & $6.4 / 6.2 / 6.3$ & $.6 / 1.2 / .8$ & $6 / 6 / 7$ & $6 / 6 / 6$ \\
\hline Total education & 10.3/10.8/9.1 & $3.1 / 3.4 / 3.9$ & $12 / 11 / 12$ & $11 / 11 / 10$ \\
\hline Experience & $5.4 / 7.4 / 8.1$ & $4.4 / 5 / 4.5$ & $1 / 15 / 15$ & $4 / 6 / 8$ \\
\hline Rental stand $\dagger$ & $4 / 54 / 40$ & - & - & - \\
\hline Continuance satisfaction & $6.7 / 6.8 / 7$ & $2.6 / 2.6 / 2.5$ & $9 / 9 / 9$ & $7 / 8.5 / 9$ \\
\hline Earnings per day & $399.8 / 307 / 277$ & $300.1 / 257 / 212$ & $900 / 100 / 110$ & $290 / 200 / 210$ \\
\hline
\end{tabular}

Foreign origin $n=178$ (immigrant traders); Johannesburg origin $n=24$; South African but not Johannesburg origin $n=101$ (migrant traders).

$\dagger$, Binary variables are represented as a percentage.

TABLE 2: Means, standard deviations, modes and medians (2010): South African origin.

\begin{tabular}{|c|c|c|c|c|}
\hline Variable & Mean/\% & Standard Deviation & Mode & Median \\
\hline Initial investment & 963.3 & 1106.2 & 350 & 500 \\
\hline Training attendance $\dagger$ & 14 & - & - & - \\
\hline Genderì & 49 & - & - & - \\
\hline Age & 37.4 & 11.4 & 39 & 37 \\
\hline Years in Johannesburg & 15 & 10.5 & 20 & 13 \\
\hline Hours worked per day & 10.8 & 2.2 & 9 & 11 \\
\hline Days worked per week & 6.28 & .9 & 6 & 6 \\
\hline Total education & 9.4 & 3.9 & 12 & 11 \\
\hline Experience & 8 & 4.6 & 15 & 8 \\
\hline Rental stand $\dagger$ & 43 & - & - & - \\
\hline Continuance satisfaction & 6.9 & 2.55 & 9 & 9 \\
\hline Earnings per day & 282.96 & 220.5 & 110 & 210 \\
\hline
\end{tabular}

$n=125$.

$n=125$.
$\dagger$, Binary variables are represented as a percentage.

\section{The sample}

In the 2008 data $12 \%$ of the respondents are of Johannesburg origin, $56 \%$ are of foreign origin and $32 \%$ are of South African origin but not Johannesburg origin. In the 2009 data $14 \%$ of traders sampled are of Johannesburg origin and $60 \%$ are of foreign origin. Therefore $26 \%$ of the sample is of South African origin, but from areas of the country other than Johannesburg. In the 2010 data $8 \%$ of the traders sampled are of Johannesburg origin, 59\% are of foreign origin and 33\% are of South African origin but are not from Johannesburg. Over the whole period relatively fewer traders of Johannesburg origin were found to be trading in this sector.

\section{Reporting and discussion of results}

Null-hypothesis 1a: There is no statistically significant difference in age by South African origin.

The Mann-Whitney test results indicate the presence of a significant difference in age by South African origin in the $2008(p<.0001)$, the $2009(p<.0001)$ and the $2010(p<.0001)$ analyses. Traders of South African origin are found to be significantly older in all three years. This corresponds with the structure of the inflows since 1994 (Peberdy \& Rogerson 2003). The prediction of isolation theory (Harris 2002), that xenophobic events may coincide with recent demographic changes, cannot be excluded.
Null-hypothesis 1b: There is no significant difference in years spent in Johannesburg by South African origin.

A significant difference in years spent in Johannesburg by South African origin is found in the 2008 data $(p<.0001)$, the 2009 data $(p<.0001)$ and 2010 data $(p<.0001)$. It was clearly evident from the results that individuals from other countries are entering the sector recently. This result is aligned with evidence of increasing inflows of traders of foreign origin into the sector over time (Gastrow \& Amit 2012; Peberdy \& Rogerson 2003).

Null-hypothesis 1c: There is no statistically significant difference in initial investment by South African origin.

Traders of foreign origin are found to invest more in their enterprises at start-up than traders of local origin in 2008 and once again in 2010. The difference in initial investment by South African origin in 2009 is not found to be significant $(p<.201)$. The significant (positive) differences in initial investment for traders of foreign origin in 2008 and 2010 support the predictions that differences in patterns of economic activity and access to resources exist between different groups by origin (Basu \& Altinay 2002; Bonacich 1973; Light 1984; Reynolds 1991; Shapero \& Sokol 1982; Wilson \& Martin 1982). It is possible that the xenophobic events (Neocosmos 2008) of 2008, which occurred after the 2008 respondents were sampled, might have influenced 
the financial structure of the sector. This might have occurred if individuals of foreign origin with higher levels of initial investment in their enterprises had left the sector temporarily. Traders of foreign origin with more resources might have been able to leave the sector at this time. To the extent that being a street trader in the inner city during times of xenophobic violence might expose one to danger, the most vulnerable individuals, those of foreign origin who could not afford to miss trading, may have had no choice but to continue in the sector, notwithstanding security concerns. Further research might indicate the further influences of xenophobic events upon street trader work, and also more specifically indicate who bears the brunt, or the costs, of these events, and in what manner.

Null-hypothesis 1d: There is no significant difference in total education by South African origin.

The analysis of the $2008(p<.0001)$ and $2009(p<.025)$ data indicates a significant difference in levels of total education by South African origin. Traders of South African origin are found to have significantly lower levels of education than traders of foreign origin across the 2008 and 2009 data. This result supports evidence in the literature that indicates that more educated individuals comprise a significant proportion of emigrants (Belot \& Hatton 2008). However, levels of education are not found to differ by South African origin in the 2010 data $(p<.237)$. This might suggest that more recently individuals of foreign origin with relatively higher levels of education might be finding other avenues of employment or self-employment on entry into the city. Alternatively, this might indicate that individuals of South African origin who are relatively more educated are entering the sector. Both of these effects might also be at work simultaneously. If so, these effects might suggest a trend towards equality in terms of educational endowments in this context. Without further evidence, these explanations are, however, tentative, and it is suggested that further research investigate the causal relationships that underlie these results.

Null-hypothesis 1e: There is no significant difference in earnings by South African origin.

According to the 2008 data, traders of South African origin earn relatively less than traders of foreign origin $(p<.069)$. However, the analysis of the 2009 data indicates that a significant difference in earnings exists: traders of South African origin earn significantly more $(p<.001)$. The frequency distribution of earnings of 2009 versus 2008 reflects the fact that, at the highest levels of earnings, local traders begin to dominate in 2009. It is possible that the incidence or the consequences of the 2008 xenophobic events influenced traders of foreign origin with the highest earnings in the sector more than traders at the lower levels of the earnings distribution. In contrast, the analysis of the 2010 data indicates that earnings differ significantly by South African origin $(p<.003)$ : traders of foreign origin are found to earn significantly more than local traders. More specifically, the traders who dominate at the highest levels of earnings are now again of foreign origin.
In order to gain a more specific understanding of these differences, an exploratory multiple linear regression analysis was performed for the 2010 data with the sample split by South African origin. The equation obtained for the traders of foreign origin $(n=177)$ with earnings as the dependent variable was found to be:

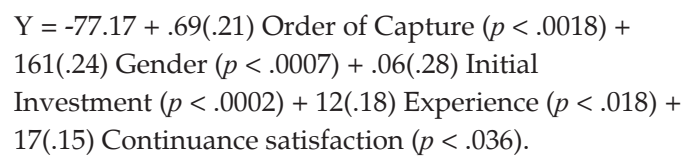

In this equation, the number before the variable is the coefficient. The numbers in brackets are the standardised coefficients. The model was found to be significant $(p<.0001)$, with an $r$-squared value of .2212 and an adjusted $r$-squared value of .1984. Thus, for traders of foreign origin, almost a fifth of the variance in earnings is found to be associated with these factors. Initial investment is found to contribute the most to earnings for traders of foreign origin, followed by male gender, experience and continuance satisfaction, in that order.

The model for traders of South African origin $(n=122)$ was also found to be significant $(p<.0001)$, with an $r$-squared of .1929 and an adjusted $r$-squared of .1793. The equation for this model is:

$Y=99.6+.08(.38)$ Initial Investment $(p<.0001)+$

15.9(.18) Continuance satisfaction $(p<.0157)$.

[Eqn 2]

A comparison of the predictors of earnings for these two groups offers further insight into differences between these groups in this sector. Surprisingly, only within the group of traders of foreign origin do male traders earn significantly more. Similarly, only within this group is there a significant association between years spent in street trading and higher earnings. This might indicate either that more recent entrants of foreign origin are earning significantly less in the sector, or alternatively that a learning effect is present for these traders that is not present for traders of local origin. Interestingly, despite the higher median initial investment of traders of foreign origin (R750) over traders of Johannesburg origin (R400) and traders of South African but not Johannesburg origin (R650), traders of South African origin seem to obtain a slightly higher return on their initial investment. Only initial investment and continuance satisfaction are found to predict earnings for traders of South African origin. The absence of significance for the gender item in this model might (hopefully) suggest that gender differentiation, or potential gender discrimination, is not a primary problem for local street traders. Causality, however, cannot be inferred, and these explanations remain tentative; further research might indicate why gender differences exist in the informal sector for traders of foreign origin.

Null-hypothesis 1f: There is no statistically significant difference in time spent in the sector by South African origin.

Traders of South African origin are found to have spent more time in the sector in all three years $(p<.0001)$. In terms of 
more recent entrants into the sector, traders of foreign origin dominate. An interpretation of these findings is that traders of foreign origin may be exiting the sector at higher rates than traders of local origin. If so, this might suggest that certain traders of foreign origin are using this sector as a temporary activity. If traders of foreign origin are using the sector in a different manner from local traders, this would be congruent with evidence in the literature that indicates that economic behaviour can differ by ethnic or cultural origin in host societies (Basu \& Altinay 2002; Bonacich 1973; Light 1984; Reynolds 1991; Shapero \& Sokol 1982; Wilson \& Martin 1982).

Null-hypothesis 1g: There is no statistically significant difference in continuance satisfaction by South African origin.

No significant difference in continuance satisfaction by South African origin was found for the 2008 data $(p<.213)$, the 2009 data $(p<.16)$ or the 2010 data $(p<.228)$. Surprisingly, traders of foreign origin are not found to be significantly more or less satisfied with continuing in street trading than traders of South African origin. Despite evidence of differences in intrinsic motivations between different immigrant groups in other contexts (Basu \& Altinay 2002), no differences in continuance satisfaction are found in this context. The nonsignificance of the 2009 association might suggest that the influence of the xenophobic events of 2008 did not have a lasting effect on the satisfaction of foreign traders with continuing in street trading as an activity in itself.

Null-hypothesis 1h: There is no statistically significant association between South African origin and product provision.

In $2008\left(\chi^{2}=7.9 ; p<.005\right)$ and in $2009\left(\chi^{2}=12.5 ; p<.0001\right)$ South African origin is found to be significantly associated with sales of vegetables and fruit as a category of product. Traders of foreign origin are significantly more likely to sell clothing in $2008\left(\chi^{2}=6.0 ; p<.014\right)$ and in $2009\left(\chi^{2}=6.0 ; p<\right.$ $.014)$. According to the analysis of the 2008 data traders of South African origin are significantly more likely to sell food $\left(\chi^{2}=9.5 ; p<.002\right)$. Traders of South African origin who sell food comprise about $14 \%$ of the sample of traders of South African origin as opposed to their counterparts of foreign origin who comprise only $4 \%$. The clustering of traders of foreign origin in clothing sales and the clustering of traders of South African origin in food supports the conception that groups exposed to a context of polarisation might cluster in different areas of activity (Harris 2002). The clustering of these traders of foreign origin in more capital-intensive product sales, such as clothing sales, supports the theory developed by Wilson and Martin (1982), which predicts that horizontal and vertical structures of trading and supply relationships can form within ethnic enclaves, or within specific immigrant groups. Of note is the possible use of such vertical international supply relationships in the sale of clothing (which is primarily imported), which contrasts with the clustering of traders of local origin in sectors that do not have an import structure, such as food sales. The results of the testing of hypotheses that relate to Johannesburg origin are reported and discussed next.
Null-hypothesis 2a: There is no statistically significant difference in age by Johannesburg origin.

The analysis of the 2008 data indicates that the zero-order point biserial correlation between Johannesburg origin and age, relative to the rest of the sample, is not significant (.054; $p<.324$ ) and neither is the same when South African origin is controlled for. The analysis of the 2009 data indicates that the zero-order point biserial correlation between Johannesburg origin and age is weakly and positively significant (.102; $p<.073)$. However, when controlling for the effect of South African origin the effect is not significant $(-.077 ; p<.179)$. The zero-order point biserial correlation between age and non-Johannesburg origin is not found to be significant in the 2010 data $(p<.704)$. However, this tests the association between traders that are of Johannesburg origin against those that are not of Johannesburg origin, which includes traders of South African origin and of foreign origin. In order to test the difference between traders of Johannesburg origin against traders not of Johannesburg origin who are also of South African origin (migrant traders), partial correlation analysis was undertaken. With South African origin controlled for, age is found to be significantly and negatively associated with Johannesburg origin $(p<.027)$. The coefficient is -.127. Age difference between traders of Johannesburg origin versus traders of South African origin is therefore significant. The median age of a trader of foreign origin is 30 years, of Johannesburg origin is 34 and of South African origin but not Johannesburg origin is 39 . Therefore, although migrants are found to be significantly younger than individuals of Johannesburg origin, immigrants are younger still. Both migration and immigration seem to be phenomena associated with relative youth in this context.

Null-hypothesis 2b: There is no statistically significant difference in initial investment by Johannesburg origin.

The analysis of the 2008 data indicates that the point biserial correlation between Johannesburg origin and initial investment is significant $(-.125 ; \mathrm{p}<.021)$, yet when the influence of South African origin is controlled for this relationship is no longer significant $(-.032 ; p<.553)$. The zeroorder point biserial correlation between initial investment and Johannesburg origin is not found to be significant for 2009 ( $p$ < .561) nor for 2010 ( $p<.145)$. After controlling for South African origin, the association between Johannesburg origin, which is now a measure of migrants versus traders of Johannesburg origin, is also not significant for 2009 $(p<.806)$ nor for $2010(p<.521)$. This indicates that the higher levels of initial investment into the sector are from immigrant traders and not from migrant traders. These results further support the notion that immigrant groups can differ in their enterprise behaviour from host country groups, and can utilise their networks to access financing advantages (Basu \& Altinay 2002; Bonacich 1973; Light 1984; Reynolds 1991; Shapero \& Sokol 1982; Wilson \& Martin 1982). Migrant groups, in contrast to immigrant groups, do not display such an advantage.

The implication of this finding is that if traders of foreign origin have higher levels of initial investment then this might 
amount to a form of foreign direct investment, or flows of capital into the country. To the extent that the informal sector is a significantly large part of the South African economy, and to the extent that about $60 \%$ of traders in this innercity context are of foreign origin in both 2009 and 2010, the cumulative impact of such potential inflows into the country might be significant.

Null-hypothesis 2c: There is no statistically significant difference in total education by Johannesburg origin.

The zero-order point biserial correlation between total education and Johannesburg origin was not found to be significant $(p<.641)$ in the 2008 data and neither is the measure of the same with the influence of South African origin controlled for $(p<.165)$. The zero-order point biserial correlation coefficient of the relationship between nonJohannesburg origin and total education is -.109 for 2009 and -.069 for 2010 with a significance of less than .056 for 2009 and less than .234 for 2010. This contrasts with the significant association found for traders of foreign origin with total education in $2009(.501 ; p<.0001)$ and 2010 (.121; $p<.035)$. However, with South African origin controlled for, non-Johannesburg origin is found to be positively and significantly associated with total education for 2010 only. This indicates that traders of non-Johannesburg origin have significantly higher levels of education than traders of Johannesburg origin in 2010. This result, from the most current data, might suggest that in the same way that higher levels of education may drive immigration across countries (Belot \& Hatton 2008), higher levels of education might also drive migration in this context.

Null-hypothesis 2d: There is no statistically significant difference in earnings by Johannesburg origin.

The zero-order point biserial correlation between Johannesburg origin and earnings is not significant according to the analysis of the 2008 data $(-.02 ; p<.715)$ and is also not for the same measure with South African origin controlled for $(.014 ; p<.795)$. The zero-order point biserial correlation between Johannesburg origin and earnings is found to be significant for $2009(.123 ; p<.031)$ yet not found to be significant for $2010(-.047 ; p<.411)$. When South African origin is controlled for this association is not found to be significant for $2009(.024 ; p<.670)$ nor for $2010(.028 ; p<.627)$. This indicates that no significant relative advantage exists for traders of Johannesburg origin versus traders of South African origin from other areas of the country. This result confirms that the differences in earnings are related to differences in immigrant status in this sector as predicted by the literature (Basu \& Altinay 2002; Bonacich 1973; Light 1984; Reynolds 1991; Shapero \& Sokol 1982; Wilson \& Martin 1982), and not by migration status. Conclusions and recommendations for further research are considered below.

\section{Conclusion and recommendations for further research}

In this research two questions were posed:

1. What are the differences in the structure of financial and contextual associations in the sector by South African and Johannesburg origin?
2. What was the potential impact of the xenophobic events of 2008 upon the financial capital structure of the innercity street trading sector?

It is concluded that fundamental differences in the financial and contextual structure of the informal inner-city street trading sector exist. Further, it is concluded that significant changes in the financial and contextual structure of the sector are associated with the time subsequent to the 2008 sample. However, these changes seem to have been temporary in nature as in 2010 the structure of financial and contextual associations were found to have reverted to the structure found in 2008. It is argued that such changes in the structure of the sector might have been a consequence of the xenophobic events of 2008.

It is concluded that the segment of traders of foreign origin are the majority in the sector yet are typically younger and have spent less time in street trading and in Johannesburg itself. Interestingly, traders of foreign origin are found to generally invest significantly more in their enterprises at start-up, and to have higher levels of education across the years 2008 and 2009. Traders of foreign origin are found to earn more in 2008, yet this relationship inverts itself in 2009 when traders of local origin are found to earn more. In 2010 this relationship reverts to its 2008 structure, as traders of foreign origin are again found to earn more. This evidence is considered to support the notion that the xenophobic events of 2008 might have financially affected street traders of foreign origin in the sector, and temporarily up-ended the earnings dominance of these traders in 2009.

It is also concluded that theory predicting polarisation or clustering differences in this context is supported, as traders of South African origin are found to cluster towards food sales, which are not significantly associated with initial investment, and traders of foreign origin are found to cluster toward clothing sales, which are found to be significantly associated with higher levels of initial investment.

Certain implications derive from these findings. These results suggest that the costs of xenophobia in this society might be borne more by street traders of foreign origin in informal inner-city street trading. It is recommended that the provision of security for street traders be enhanced through the interventions of policymakers. Further qualitative research, particularly using ethnographic methods, is recommended, particularly given that this research has not demonstrated any causal relationship, but rather has presented findings that support the argument.

It is also suggested that policymakers consider the human costs associated with xenophobic events; it is possible that these events require proactive planning of security at these times. Cameras throughout the areas that cover street trading might improve security. Further, because immigrant traders often find themselves under threat from the state machinery (in the form of police raids and other laws that influence them), it is argued that further research investigate the 
human cost of these influences on these people. With better knowledge of the human costs imposed on these human beings, policymakers might be more inclined to pursue more humanist policies, or policies to reduce the human cost borne by these people.

It is argued that the research of informal sector trading in the Southern African context incorporates the potential influence of xenophobia on enterprise. Further research is suggested into the impact, and benefits, of cumulative large-scale financial investment in the informal sector by individuals of foreign origin.

\section{Acknowledgements Competing interests}

The author declares that he has no personal or financial relationship(s) that may have inappropriately influenced him in writing this article.

\section{References}

Basu, R.A. \& Altinay, E., 2002, 'The interaction between culture and entrepreneurship in London's immigrant businesses', International Small Business Journal 20(4), 371-393. http://dx.doi.org/10.1177/0266242602204001

Becker, G.S., 1975, Human Capital, 7th edn, University of Chicago Press, Chicago.

Belot, V.K. \& Hatton, T.J., 2008, Immigrant selection in the OECD, discussion paper no. 571, viewed 21 October 2012, from http://cbe.anu.edu.au/research/papers/ ceprdpapers/DP571.pdf

Bonacich, E., 1973, 'A theory of middleman minorities', American Sociological Review 38, 583-594. http://dx.doi.org/10.2307/2094409

Callaghan, C.W. \& Venter, R., 2011, 'An investigation of the entrepreneurial orientation, context and entrepreneurial performance of inner-city Johannesburg street traders', Southern African Business Review 15(1), 28-48.

Chipkin, I., 2007, Do South Africans Exist? Democracy, Nationalism and the Identity of 'The People', University of the Witwatersrand Press, Johannesburg.

Coleman, J.S., 1988, 'Social capital in the creation of human capital', American Journal of Sociology 94, S95-S120. http://dx.doi.org/10.1086/228943

Coulthard, M., 2007, 'The role of entrepreneurial orientation on firm performance and the potential influence of relational dynamism', Journal of Global Business and Technology 3(1), 29-39.

Cresswell, J.W., 2003, Research Design. Qualitative, quantitative and mixed methods approaches, 2nd edn., Sage, Thousand Oaks, CA.

Crush, J., 1999, 'Fortress South African and the Deconstruction of Apartheid's Migration Regime', Geoforum 30, 1-11. http://dx.doi.org/10.1016/S00167185(98)00029-3

Crush, J. \& Frayne, B., 2007, 'The migration and development nexus in Southern Africa Introduction', Development Southern Africa 24(1), 1-23. http://dx.doi. org/10.1080/03768350601165710

Dasgupta, S., 2003, 'Structural and behavioural characteristics of informal service employment: Evidence from a survey in New Delhi, The Journal of Development Studies 39(3), 51-80. http://dx.doi.org/10.1080/00220380412331322821

De Soto, H., 1989, The Other Path, Harper \& Row, New York.

Dubini, P. \& Aldrich, H., 1991, 'Personal and extended networks are central to the entrepreneurial process', Journal of Business Venturing 6, 305-313. http://dx.doi. org/10.1016/0883-9026(91)90021-5

Duncan, N., 2012, 'Reaping the whirlwind: Xenophobic violence in South Africa', Global Journal of Community Psychology Practice 3(1), viewed 01 September 2013, from http://www.gjcpp.org/en/resource. php?issue $=10 \&$ resource $=52$

Gastrow, V. \& Amit, R., 2012, Elusive Justice. Somali traders' access to formal and informal justice mechanisms in the Western Cape, ACMS research report, viewed 21 October 2012, from http://www.irinnews.org/pdf/ElusiveJustice_17October. 21 pdf

Harber, A., 2008, 'Two newspapers, two nations', in S. Hassim, T. Kupe \& E. Worby (eds.), Go home or die here: Violence, xenophobia and the reinvention of difference in South Africa, pp. 161-174, Wits Press, Johannesburg.

Harris, B., 2002, 'Xenophobia: A new pathology for a new South Africa?' in D. Hook \& G. Eagle (eds.), Psychopathology and Social Prejudice, University of Cape Town Press, Cape Town.

Hjerm, M., 1998, 'National Identities, National Pride and Xenophobia: A Comparison of Four Western Countries', Acta Sociologica 41, 335-347.
Hussein, Q., 2012, South Africa's xenophobia claims ten Somali traders in five days, viewed 21 October 2012, from http://somalilandpress.com/south-africasxenophobia-claims-ten-somali-traders-in-five-days-30612

Landau, L.B. \& Monson, T., 2007, 'Displacement, Estrangement and Sovereignty: Reconfiguring State Power in Urban South Africa', Government and Opposition 43(2), 315-336.

Le, W., Van der Straeten, K. \& Roemer, J., 2006, 'Racism, Xenophobia, and Redistribution', Journal of the European Economic Association 4(2-3), 446-454. $\mathrm{http}: / / \mathrm{dx}$.doi.org/10.1111/j.1477-7053.2007.00252.x

Light, I., 1984, 'Immigrant and ethnic enterprise in North America', Ethnic and Racia Studies 7(2), 195-216. http://dx.doi.org/10.1080/01419870.1984.9993441

Ligthelm, A., 2006, 'An evaluation of the role and potential of the informal economy for employment creation in South Africa', South African Journal of Labour Relations 30(1), 30-50.

Mamdani, M., 2001, 'Beyond Settler and Native as Political Identities: Overcoming the Political Legacy of Colonialism', Comparative Studies in Society and History 43(4), 651-664.

Moorhouse, L. \& Cunningham, P., 2010, 'Permanently "in process": The intersection of migration, work identity and the reality of human resource development in the South African context', Human Resources Development International 13(5), 587-597. http://dx.doi.org/10.1080/13678868.2010.520483

Myers, S.L., Lange, J.T. \& Corrie, B., 2003, 'The political economy of antiracism initiatives in the post-Durban round', American Economic Review 93(2), 330-333. http://dx.doi.org/10.1257/000282803321947290

Ndlovu-Gatsheni, S.J., 2011, 'The World Cup, vuvuzelas, flag-waving patriots and the burden of building South Africa', Third World Quarterly 32(2), 279-293. http:// dx.doi.org/10.1080/01436597.2011.560469

Neocosmos, M., 2008, 'The politics of fear and the fear of politics: Reflections on xenophobic violence in South Africa', Journal of Asian and African Studies 43(6), 586-594. http://dx.doi.org/10.1177/0021909608096655

O'Reilly, T., 2004, 'Street traders', viewed 17 March 2005, from http://www.joburg. org.za/2004/jan/jan21_traders.stm

Peperdy, S. \& Rogerson, C.M., 2003, 'South Africa: Creating new spaces?', in R. Kloosterman \& J. Rath (eds.), Immigrant Entrepreneurs. Venturing Abroad in the Age of Globalisation, Berg, New York.

Roberts-Lombard, M., 2009, 'Customer retention strategies implemented by fastfood outlets in the Gauteng, Western Cape and Kwazulu-Natal provinces of South Africa: A focus on Something Fishy, Nando's and Steers', African Journal of Marketing Management 1(2), 70-80.

Roemer, J.E. \& Van der Straeten, K., 2005, 'Xenophobia and the size of the public sector in France: A politico-economic analysis', Journal of Economics 86(2), 95144. http://dx.doi.org/10.1007/s00712-005-0142-x

Roemer, J.E. \& Van der Straeten, K., 2006, 'The political economy of xenophobia and distribution: The case of Denmark', Scandinavian Journal of Economics 108(2), 251-277. http://dx.doi.org/10.1111/j.1467-9442.2006.00450.x

Rogerson, C., 1997, 'Local economic development and post-apartheid South Africa', Singapore Journal of Tropical Geography 18, 175-195. http://dx.doi. org/10.1111/1467-9493.00015

Shapero, A. \& Sokol, L., 1982, 'The social dimensions of entrepreneurship', in C.A. Kent, D.L. Sexton \& K.H. Vesper (eds.), Encyclopaedia of Entrepreneurship, pp. 72-90, Prentice-Hall, Englewood Cliffs, NJ.

Statistics South Africa, 2008, Quarterly Labour Force Survey: Quarter 3, statistical release P0211, viewed 18 January 2009, from http://www.statssa.gov.za/ publications/statsdownload. asp?PPN=P0211\& $\mathrm{SCH}=4255$

Tissington K., 2009, The Business of Survival: Informal Trading in Inner City Johannesburg, Centre for Applied Legal Studies (CALS), viewed 11 January 2011 from http://web.wits.ac.za/NR/rdonlyres

Trading Economics, 2013, South Africa unemployment rate, viewed 12 September 2013, from http://www.tradingeconomics.com/south-africa/unemployment-rate

Trimikliniotis, N., Gordon, S. \& Zondo, B., 2008, 'Globalisation and Migrant Labour in a "Rainbow Nation": A fortress South Africa?', Third World Quarterly 29(7) 1323-1339. http://dx.doi.org/10.1080/01436590802386476

Urban, B., 2006, 'ESE in a multicultural society: Measures and differences', South African Journal of Industrial Psychology 21(1), 2-10.

Van Rooyen, E. \& Antonites. A., 2007, 'Formalising the Informal Sector: A Case Study on the City of Johannesburg', Journal of Public Administration 42(3), 324-346.

Venter, R.B., Rogerson, C.M., Semens, A. \& Myres, K., 2012, 'FIFA World Cup 2010 Implications for and effects on the entrepreneurial performance of South Africa's informal sector', African Journal of Business Management 6(1), 449-458.

Verryn, P., 2008, 'Foreword', in S. Hassim, T. Kupe \& E. Worby (eds.), Go home or die here: Violence, xenophobia and the reinvention of difference in South Africa, pp. vii-viii, Wits Press, Johannesburg.

Wilson, K.L. \& Martin, W.A., 1982, 'Ethnic enclaves: A comparison of the Cuban and Black economies in Miami', American Journal of Sociology 88, 135-160. http:// dx.doi.org/10.1086/227637

Worby, E., Hassim, S. \& Kupe, T., 2008, 'Introduction', in S. Hassim, T. Kupe \& E. Worby (eds.), Go home or die here: Violence, xenophobia and the reinvention of difference in South Africa, pp. 1-26, Wits Press, Johannesburg. 